\title{
AİHM’İN HÜKÜMETE SON SÖZÜ: “ALEVİLERİ RESMEN TANI”
}

\author{
The Last Words of EHRC to Turkish Government: "Recognize the Alevis Officially"
}

\section{Der europäische Gerichtshof für Menschenrechte hat zum letzten mal die türkische Regierung aufgefordert, "Die Aleviten offiziell anzuerkennen”!}

\author{
Haydar EFE*
}

DOI: http://dx.doi.org/10.22520/abked.2016.14.0004

Alevilik inancı pek çok bakımdan Sünni İslam anlayışından farklı nitelikleri içinde barındıran bir inançtır. Aleviler Türkiye'deki ikinci büyük dinsel topluluktur ve Türkiye'de Alevi inancına mensup en az 15 milyon insanın var olduğu tahmin edilmektedir. Türkiye Cumhuriyeti'nin laik yapısına rağmen, İslami din hizmetleri Türkiye'de kamu hizmeti olarak görülmektedir. Fakat Aleviler bu hizmetlerden yararlanamamaktadır.

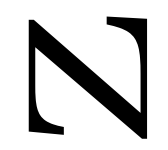
Yalnızca Sünni Müslümanlara yönelik dinsel kamu hizmeti, kamu hizmetlerinin tarafsızlığ1 ve laiklik ilkesiyle de bağdaşmaz. Ayrıca, Aleviler Diyanet İşleri Başkanlığı’'nın (DİB) yapısı, zorunlu din dersleri, ibadet yerleri olan cemevlerinin ibadethane olarak resmen tanınmaması

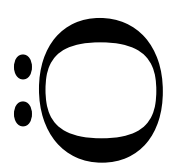
gibi pek çok sorunla karşı karşıyadırlar. Aleviler devletten Alevi inancının uygulanması için bütçe tahsis etmesini; Alevi dini liderlerinin devlet memuru olarak istihdam edilmesini ve Alevilerin ibadet yeri olan cemevlerine ibadethane statüsü verilmesini talep etmektedirler.

$\mathrm{Bu}$ makalenin temel amacı, din ve inanç özgürlüğü kapsamında Avrupa İnsan Hakları Mahkemesi’nde (AİHM) Alevilerin sorunlarıyla ilgili görülen davaları ve sonuçlarını analiz etmektir.

Anahtar Sözcükler: AİHM, Alevi, Alevilik, Alevilerin sorunları

* Doç. Dr., Erzincan Üniversitesi, Siyaset Bilimi ve Kamu Yönetimi Bölümü. 


\begin{abstract}
Alevi faith is a belief with particular features which distinguished it in many respects from the Sunni understanding of İslam. Alevis are the second largest religious community and it is estimated that there are at least 15 million followers of the Alevi faith in Turkey. Despite the secular nature of the Republic of Turkey, İslamic religious service is regarded as a public service in Turkey. But, Alevis cannot benefit from these services. Public service that exclusively to Sunni Muslim is incompatible with the constitutional principles of secularism and neutrality of public services. In addition, Alevis have many problems such as formation of Religious Affairs Department (RAD), compulsory religious education, demand of recognition for their places of worship, namely the cemevis. They want their State to allocate budget for practice of the Alevi faith; recruit Alevi religious leaders as civil servants; grant the Alevi places of worship (cemevis) to the status of places of worship.

Main aim of this article is analize to the European Court of Human Rights's cases (ECHR) about Alevis' problems within the context of the right to freedom of conscience and religion and its conclusions.
\end{abstract}

Key Words: ECHR, Alevi, Alevism, problems of Alevis 


\section{ZUSAMMENFASSUNG}

Der alevitische Glaube ist eine Verkündigung, der viele unterschiedliche Eigenschaften in sich verbirgt und sich dadurch in vielerlei Hinsicht von der sunnitischen Islamdeutung unterscheidet. Die Aleviten bilden die zweitgrößte Religionsgemeinschaft in der Türkei und es wird vermutet, dass in der Türkei mindestens 15 Millionen Menschen der alevitischen Glaubenswahrheit angehören. Obwohl die Republik Türkei laizistisch aufgebaut ist, werden die islamischen Religionsdienste in der Türkei als Aufgabe des öffentlichen Dienstes verstanden. Die Aleviten können jedoch von diesen Diensten nicht profitieren. Darüber hinaus ist es auch nicht mit dem Prinzip der Neutralität - des Staates - und dem Grundsatz des Laizismus vereinbar, dass die öffentlichen Religionsdienste nur an die sunnitischen Muslime adressiert werden. Darüber hinaus sind die Aleviten mit einer Reihe von Problemen konfrontiert, welche die Struktur des Präsidiums für Religionsangelegenheiten (DIB), den verpflichtenden Religionsunterricht für alle und die Anerkennung der alevitischen Gebetshäuser (cemevi) als offizielle Gotteshäuser betreffen. Die Aleviten fordern vom Staat, Budgets für die Ausübung des alevitischen Glaubens zur Verfügung zu stellen, die religiösen Führer der Aleviten als Staatsbeamte anzustellen und den alevitischen Gebetsstädten (cemevi) einen offiziellen Status als Gotteshaus zu geben.

Dieser Artikel verfolgt im wesentlichen das Ziel, die Klagen und Prozessergebnisse, die vom Europäischen Gerichtshof für Menschenrechte über Aleviten behandelt werden, im Rahmen der Religions- und Glaubensfreiheit zu analysieren.

Schlüsselbegriffe: EGMR, Alevite, Alevitum, die Probleme der Aleviten 


\section{Giriş}

Orta Asya'da ortaya çıkan ve büyük ölçüde Hoca Ahmet Yesevi ve Hacı Bektaş Veli gibi inanç önderleri sayesinde Anadolu'da gelişen Alevilik, kaynağını büyük ölçüde Türk toplumundan ve Türk tarihinden almıştır. İslam tasavvufundan ve İslamiyet öncesi inanç sistemlerinden etkilenen ve ibadet, dua, namaz ve oruç gibi konularda Sünni İslamdan farklılıklar gösteren Aleviliği, Yaman, (2007: 30) yazılı olmaktan çok sözlü geleneğe dayalı, eski inançların İslami şekiller altında yaşamaya devam ettiği bir halk İslamı olarak nitelendirmektedir. Günümüzde Türkiye'de Sünni İslam'dan sonra en büyük ikinci inanç grubunu oluşturan Aleviler, İslamiyet öncesi eski inançları olan Şamanizm ve Zerdüştlük inanışlarındaki ibadet biçimlerini cemlerine taşımışlardır.

Aleviler, cemevlerinin statüsü, zorunlu din dersleri ve tanınma gibi pek çok sorunla karşı karşıyadır. Türkiye, laik bir devlet olmasına rağmen, din hizmetleri Diyanet İşleri Başkanlığ1 (DİB) tarafından "kamu hizmeti" olarak verilmektedir. Ancak, söz konusu kurum, Aleviliği sufi tarikat olarak görmekte, Sünni vatandaşlara verdiği hizmeti Alevilerden esirgemektedir. Bir kamu hizmetinin sadece Sünni mezhep üyelerine sunulması hem laiklikle bağdaşmamakta hem de kamu hizmetlerinin tarafsızlığ1 ve eşitlik ilkeleriyle de bağdaşmamaktadır.

Söz konusu sorunlarla ilgili olarak Aleviler, dini bir cemaat olarak tanınmadıklarından ve tüzel bir kişilikleri bulunmadığından ancak vakıf ve dernekler yoluyla dava açabilmektedir. Alevilerin tanınmaması ve tabi oldukları yasal bir çerçevenin bulunmaması, pek çok sorunlara sebep olmaktadır. Yukarıda ifade edildiği gibi, Aleviler tüzel kişilikleri bulunmadığından dava açamamakta, ibadet yeri inşa edememekte ve devletten yardım alamamaktadır. Dini liderlerinin hiçbir yasal statüsü bulunmamaktadir.

Bu kapsamda, pek çok kez yargıya müracaat eden ve bir sonuç alamayan Aleviler, iç hukuk yollarını tükettikten sonra sorunları Avrupa İnsan Hakları Mahkemesi'ne (AİHM) taşımışlar ve açılan davaların tümünde mahkemece haklı bulunmuşlardır.

Bu çalışma, AİHM'nin Büyük Dairesi'nin Alevilerle ilgili verdiği karar başta olmak üzere, AİHM'nin Alevilerle ilgili olarak baktığı davalarda verdiği, yalnız Alevi yurttaşlarımız açısından değil Ezidiler, Süryaniler ve Keldaniler gibi azınlıktaki diğer dini cemaatler açısından da önemli olan zorunlu din dersleri konusunda HasanEylem Zengin Davası ve Mansur Yalçın ve Diğerleri Davas1; cemevlerinin statüsü 
konusunda Cumhuriyetçi Eğitim ve Kültür Merkezi Vakfı/Türkiye Davası ve son olarak AİHM'nin Büyük Dairesi'nin vermiş olduğu İzzettin Doğan ve Diğerleri Davası'nın kararları ve kararların etkileri ve sonuçları analiz edilecektir.

\section{Zorunlu Din Dersleri Hakkındaki AİHM Kararları}

Zorunlu din dersleriyle ilgili olarak, AİHM'de görülen Hasan ve Eylem Zengin Davası Alevilerin AİHM'nde kazandıkları üç büyük davadan birincisidir. 2001 yılında Hasan Zengin 7. sınıfta okuyan Eylem Zengin isimli kızının zorunlu din derdinden muaf tutulmasını İstanbul Milli Eğitim Müdürlüğü’nden istemiş, ancak olumsuz yanıt verilmesi üzerine Zengin, İstanbul İdare Mahkemesi’ne başvurmuş, Mahkemenin, Zengin’in söz konusu talebini reddetmesinin ardından, Danıştay da 14 Nisan 2003 tarihinde başvuranın itirazını reddetmiş ve ilk derece mahkemesinin kararını onamıştır. (Hasan Eylem Zengin/Türkiye Davası, (Başvuru no. 1448/04)) Hasan ve Eylem Zengin, iç hukuk yollarını tükettikten sonra 2 Ocak 2004 tarihinde AİHM'ne Zorunlu Din Kültürü ve Ahlak Bilgisi Derslerinin (DKAB) Avrupa İnsan Hakları Sözleşmesi'nin 1 Numaralı Protokolü'nün “Devlet eğitim ve ögretim alaninda yükleneceği görevlerin yerine getirilmesinde, ana ve babanın bu eğitim ve ögretimin kendi dini ve felsefi inançarma göre yapılmasın sağlama haklarma saygı gösterir’ şeklindeki 2. maddesinin 2. cümlesinde güvence altına alınan hakların ihlal edildiği iddiasını ileri sürmüştür.

Başvuranlar, DKAB derslerinin tarafsız, eleştirel ve çoğulcu bir şekilde işlenmediğini ve dolayısıyla AİHM tarafindan 1 No.lu Protokol'ün 2. maddesi bağlamında belirlenen ölçütlere uymadığını ileri sürmüşler ve söz konusu derslerde İslam inanç ve geleneğinin Sünni yorumunu yücelten ders programı ve Sünni İslamiyetin geleneksel adetlerini anlatan ders kitaplarının eğitimin tarafsız yapılmadığının kanıtı olduğu iddia edilmiştir. Söz konusu derslerin program ve içeriğinin başvuranların inancının varlığını reddeder ve İslamın Sünni yorumunu öğretir şekilde düzenlendiğini iddia etmiştir. (Hasan Eylem Zengin/Türkiye Davası, (Başvuru no. 1448/04))

Hükümet, savunmasında Milli Eğitim Bakanlığı tarafından hazırlanan DKAB dersinin devlet denetiminde yürütülmesinin sebebinin suistimali önlemek olduğunu iddia ederek, devletin bu alanda takdir yetkisine sahip olduğunu ve AİHM'nin yerleşik içtihadının, müfredatın düzenlenmesi ve içeriğinin devletin takdir yetkisi içinde olduğunun altını çizmiştir. Dolayısıyla, 1 No.lu Protokol'ün 2. maddesinin, ebeveynlerin devletin bu yetkisine itiraz etmelerini mümkün kılmadığını savunmuştur. Hükümet, ayrıca, DKAB ders programının Anayasanın 24. maddesine ve 1739 sayılı 
Milli Eğitim Temel Kanunu'nun 12. maddesiyle uyumlu olduğu ve mezhebe dayalı bir eğitim yapılmadığını ifade etmiştir. DKAB derslerinde belli bir dinin öğretilerine ve adetlerine ilişkin özel bir eğitim verilmediği, farklı dinler hakkında genel bilgi aktarıldığı öne sürülmüştür. (Hasan Eylem Zengin/ Türkiye Davası, (Başvuru no. 1448/04))

Hükümet, dersin zorunlu olmasının, çocukları, fanatizme yol açan uydurma hikayelerden ve yanlış bilgilerden koruma gerekliliğinden kaynaklandığını vurgulamıştır. Hükümet, ayrıca, derslerin nesnel, çoğulcu ve tarafsız bir şekilde öğretildiği sürece öğrencilere Müslüman inancına ilişkin öğretim sağlamanın da AİHS uyarınca bir sorun oluşturmayacağını iddia etmiştir. Musevi ve Hıristiyanların bu derslerden muaf tutulduğunu ve ateist olan bireylerin muaf tutulmak istemeleri halinde taleplerinin yetkililer tarafindan değerlendirileceği belirtilmiştir. ${ }^{1}$ (Hasan Eylem Zengin/ Türkiye Davası, (Başvuru no. 1448/04))

Avrupa'da din eğitimi veren devletlerin hemen hemen tamamının, öğrencilere din eğitimi alma dişında muafiyete tabi tutmak veya o dersin yerine geçebilecek bir başka derse katılmalarını sağlamak veya öğrencilere din derslerine kaydolma veya olmama seçeneği tanımak gibi en az bir seçenek sunduğunun altını çizen AİHM, (Hasan Eylem Zengin/Türkiye Davası, (Başvuru no. 1448/04)) devletin eğitim programının tamamı boyunca ebeveynlerin, dini ve felsefi inançlarına sayg1 göstermesi gerektiğini ifade etmiştir. Ayrıca, söz konusu görevin kapsamının geniş olduğu, yalnız dersin içeriği ve sağlanma şekliyle sınırlı olmadığını, aynı zamanda, devlet tarafından üstlenilen tüm görevlerin icra edilmesini de kapsadığına dikkat çekmiştir. AİHM’ye göre, "sayg1 göstermek" fiili, "kabul etmek" veya "göz önünde bulundurmak"tan daha fazla bir anlam taşımaktadır. Yani, doğrudan negatif bir taahhüdün yanı sıra devlete pozitif bir yükümlülük de yüklemektedir.

AİHM, müfredatın düzenlenmesinin ve planlanmasinın da taraf devletlerin yetkisinde bir konu olduğunu kabul etmiş, ancak 1 No.lu Protokolün 2. maddesinde yer alan ikinci cümlesi, devletin eğitim ve öğretimle ilgili olarak, üzerine düşen görevleri yerine getirirken, öğrencilerin, yersiz bir din benimsetme uğraşından uzak, sakin bir ortamda, dinle ilgili olarak eleştirel bir bakış oluşturmalarını sağlayacak şekilde müfredatta yer alan bilgilerin nesnel, eleştirel ve çoğulcu bir şekilde aktarılmasına dikkat etmesi gerektiğine işaret etmiştir. Devletin ebeveynlerin

1 Hasan ve Eylem Zengin -Türkiye (Başvuru no. 1448/04) Avrupa Konseyi Avrupa İnsan Hakları Mahkemesi Karar Strazburg, 9 Ekim 2007, 
dini ve felsefi kanaatlerine sayg1 gösterilmemesi olarak değerlendirilebilecek tek yönlü koşullandırma (indoctrination) hedefi gütmesinin yasaklandı̆̆ı hatırlatılarak, aşılmaması gereken eşiğin de bu olduğunun altını çizmiştir. (Hasan Eylem Zengin/ Türkiye Davası, (Başvuru no. 1448/04))

Mahkeme, ayrıca, çoğulcu demokratik bir toplumda devletin çeşitli dini, inanç ve düşüncelere karşı tarafsız ve yansız olma ödevinin, dini inançların veya bunların sergilenme yöntemlerinin meşruluğuna ilişkin olarak devlet tarafindan yapılacak herhangi bir değerlendirme ile uyuşmadığını her zaman vurguladığını hatırlatmıştır. Ayrıca, devletin dini toplulukların birleştirilmiş bir liderlik altında toplanmaları veya kalmaları için bir tedbir almasına gerek bulunmadığını ifade etmiştir

Mahkeme'ye göre, 'başvuranlarm inanc olan Alevilik inancmm özelliklerine nazaran İslamın Sünni anlayısı arasında var olduğunu iddia ettikleri fark o kadar önemlidir ki, bu fark.ın salt ders kitaplarnda yer verilen alevi inancma ve ibadetlerine iliskin bilgilerle yeterince bafifletilmesi oldukesa zor olabilecektir.' Seçmeli din dersi kapsamında öğrencilere daha kapsamlı bilgilerin iletilebileceğine ilişkin Hükümet iddiasıyla ilgili olarak da Mahkeme, böylesi bir imkanın devleti, zorunlu din dersi öğretiminin tarafsızlık ve çoğulculuk ilkelerine uygun olarak verilmesini sağlama yükümlülüğünden muaf tutamayacağını ifade etmiştir. (Hasan Eylem Zengin/ Türkiye Davası, (Başvuru no. 1448/04))

Derslerde kullanılan ders kitaplarının hükümetin ifade ettiği gibi dinler hakkında genel bilgi sağlamakla sınırlı kalmadıklarını, İslam bilgisine diğer din ve felsefelere göre daha çok yer verildiğini ifade eden AİHM, söz konusu durumun Türkiye'de yaşayanların çoğunun Müslüman olduğu dikkate alındığında tek başına çoğulculuk ve nesnellik ilkelerinden tek yönlü koşullandırmaya (indoctrination) yol açan bir sapma olarak görülemeyeceğini, ancak AİHS'ye taraf devletlerin 1 No.lu Protokol'ün 2. maddesinin ikinci cümlesi kapsamındaki, ebeveynlere din öğretiminde kendi dini ve felsefi inançlarına saygı gösterilmesini devletten talep etme hakk1 veren olumlu yükümlülüklerini hatırlatmıştır. Bu kapsamda, sözleşmeye taraf bir devletin din derslerinde öğrencilerin, okulun verdiği din eğitimiyle ebeveynlerin dini ya da felsefi inançları arasında doğacak bir çatışmayla karşı karşıya kalmalarını olabildiğince önlemenin gerekli olduğu sonucuna vararak "Eylem Zengin'in Alevi inancona mensup babasınm, ders programında eksik olduğu açıkça görülen dini ve felsefi kanaatlerine sayg gösterdiğinin söylenemeyeceği kanaatine" varmıştır. (Hasan Eylem Zengin/Türkiye Davas1, (Başvuru no. 1448/04)) 
Mahkeme, ayrıca, ebeveynlerin çocuklarının söz konusu dersten muaf tutulabilmeleri için Hıristiyanlık ya da Musevilik dinine mensup olduklarını okula önceden bildirme zorunluluğunun da Türkiye Cumhuriyeti Anayasası'nın 24. maddesinin "kimsenin dini inanç ve kanaatlerini açıklamaya zorlanamayacağını" ifadesine aykırı olduğu ve dolayısıyla, AİHS'nin 9. maddesi çerçevesinde bu durumun sorun yaratabileceğini ifade etmiştir.

Hükümetin, muafiyet olasılığının, talep geldiği takdirde diğer inançlar için de genişletilebileceğini ifade etmesine karşıllk olarak, mahkeme, muafiyetin kapsamı ne olursa olsun, ebeveynlerin okul yetkililerine dini ve felsefi inançlarını bildirmelerinin zorunlu olmasının, inanç özgürlüklerine saygı gösterilmesi için uygun bir araç olmadığını, din dersinden muafiyet işleminin, farklı dini veya felsefi inançlara sahip aileleri ağır bir yük altına sokabilmekte ve onları çocuklarının din dersinden muaf tutulmaları için dini ya da felsefi inançlarını ifşa etmeye mecbur bıraktığı ve dolayısıyla muafiyet yönteminin uygun bir yöntem olmadığının altını çizmiştir. Ayrıca, Devletin, dini çoğulculuk da dahil olmak üzere, demokratik bir toplumda çoğulculuğun nihai teminatçısı olarak, konu hakkındaki düzenleme yetkisinin uygulanmasında ve çeşitli dinler, ibadetler ve inançlarla olan ilişkisinde yansız ve tarafsız olması gerektiğine vurgu yapmıştır. Sonuç olarak, başvuranların haklarının ihlal edildiği sonucuna varmıştır. (Hasan Eylem Zengin/Türkiye Davas1, (Başvuru no. 1448/04))

Mahkeme, devletin bu konudaki rolünün başkalarına zarar verecek şekilde dini yorumlardan birine ayrıcalık tanımaya ya da başka bir dini topluluğu veya bu topluluğun bir kısmını rızası olmaksızın birleşik bir yönetim altında toplamaya veya böyle bir yönetime maruz bırakmaya yönelik önlemler almayı kapsamadığının altını çizmiştir.

Zorunlu din dersleri konusunda 2 Şubat 2011 tarihinde AİHM'de açılan Mansur Yalçın ve Diğerleri/Türkiye Davası da önemli bir diğer davadır. ${ }^{2}$ (Mansur Yalçın ve Diğerleri/Türkiye Davas1, (Başvuru No. 21163/11),) Davada, ilk ve orta dereceli okullarda zorunlu olarak okutulan DKAB dersinin işlenme biçiminin AİHS'ne ek 1 No.lu Protokol'ün 2. maddesinin ikinci cümlesinin yanı sıra, sözleşmenin $9^{3}$ ve

2 Mansur Yalçın ve Diğerleri/Türkiye Davası, Avrupa İnsan Hakları Mahkemesi, (Başvuru No. 21163/11), Strazburg, 16 Eylül 2014.

3 AİHS 9. madde "Düşünce Din ve Vicdan Özgürlüğü, Herkes, düşünce din ve vicdan özgürlüğüne sahiptir; bu hak din veya inanç değiştirme özgürlügü ile tek başına veya topluca, kamuya açık veya kapalı ibadet, öğretim uygulama ve ayin yapmak suretiyle dinini veya inancını açıklama özgürlüğünü de içerir.” 
14. maddeleri ${ }^{4}$ bağlamındaki haklarını ihlal ettiğini ileri sürmüşlerdir. DKAB ders programının Alevi inancına mensup din büyükleriyle konuşularak hazırlanması ve ders müfredatında Alevilerin kültür ve felsefesine yer verilmesi talep edilmiştir.

Hükümet, 2009 ve 2010 yıllarında yapılan Alevilik Çalıştayı'nın da MEB'e bağlı Din Öğretimi Genel Müdürlüğ̈̈nce DKAB dersleri programının yeniden düzenlenmesinin kararlaştırıldığı, bu kapsamda görüş alış verişinde bulunmak ve farklı inançların taleplerini belirlemek amacıyla, Alevi Bektaşi, Caferi ve Nusayri önderlerinin katılımıyla bir dizi toplantı gerçekleştirildiği, Alevi Bektaşi, Caferi ve Nusayri temsilciler tarafından düzenlenen raporun sonuçları doğrultusunda müfredat ve ders kitapları, bu toplulukların önderleri tarafindan dile getirilen talepleri, Hükümet'e göre, büyük oranda karşılayacak şekilde değiştirildiğini ifade etmiştir. (Mansur Yalçın ve Diğerleri/Türkiye Davası, (Başvuru No. 21163/11))

Başvuranlar, Mahkeme’ye konu ile ilgili olarak hazırlanmış raporlar sunmuşlardır. Raporlardan birincisi, Mustafa Cemil Kılıç tarafından 23 Ocak 2013 tarihinde hazırlanan "Din Dersi Sorunu” başlıklı rapordur. Söz konusu raporda (Kılıç, 2013) Aleviliğin, ders kitaplarında bir mezhep olarak kabul edilmediği, daha alt düzeyde ele alınıp deyim yerindeyse itibar ve değerinin düşürülmek istendiği ifade edilmektedir.

İkinci belge ise, "Zorunlu Din Kültürü ve Ahlak Bilgisi Dersi: "Çoğulcu "Mezheplerüstü” ve Çoğunluk Mezhepçiliği Arasında” başlıklı rapordur. Yaman'ın kaleme aldığı belgede, (Yaman, 2013) Türkiye’de din eğitimi ve hizmetleri alanında Sünni kadroların tercih edildiği, Alevilerin de vergilerinden oluşan genel bütçeden yalnız Sünni din adamları atandığı, Sünniliği esas alan ders içeriği ve Sünni eğitim almış bir eğitimci kadrosuyla verilen Din Kültürü ve Ahlak Bilgisi kadrosunun verdiği derslerin "mezhepler üstü" olduğunu iddia etmenin doğru olmadığını, Sünni inanç ve kültürüyle yetişmiş din adamlarının Alevilik öğretiminin sıkıntılı olacağının altını çizmiştir. 5. sınıf ders kitabından örnek veren Yaman, namazın kitapta resimlerle anlatıldığı, Caminin de ayrıntılı olarak açıklanmasına karşın Aleviliğin herhangi bir kurum ya da kuralına yer verilmediği, dolayısıyla, Alevi öğrencilerin zorunlu olan bu derste başlıca ibadetleri öğrenirken, Sünni anlayış dışında bir bilgi edinmesinin mümkün olmadı̆̆ını ifade etmiştir.

4 AİHS 14. Madde “'Ayrımcılık Yasağı, Bu sözleşme'de tanınan hak ve özgürlüklerden yararlanma cinsiyet, 1rk, renk, dil, din, siyasal veya diğer kanaatler, ulusal veya toplumsal köken, ulusal bir azınlı̆ga aidiyet, servet, doğum başta olmak üzere herhangi başka bir duruma dayalı hiçbir ayrımcılık gözetilmeksizin sağlanmalıdır.” 
Yaman ayrıca, zorunlu din derslerinden yalnız Alevilerin olumsuz etkilenmediği, ayrıca bir kısım Sünni vatandaşların da aralarında olduğu çok çeşitli grupların bu durumdan şikayetçi olduğunu ifade ederek, zorunlu din derslerindeki Alevilikle ilgili bölümlerin Alevilerce hazırlanması, mevcut Sünni eğitimcilerin Alevilik konusunda hem önyargılı hem de yeterli bilgi sahibi olmadıklarını ifade ederek, Alevilikle ilgili dinsel hizmetleri görecek kadroların yetiştirilmesi için gerekli eğitim kurumları kurulmasını ve eğitimci kadrosunun yetiştirilmesini önermiştir. (Yaman, 2013)

Başvuranların sunduğu üçüncü belge ise Mine Yıldırım tarafından kaleme alınan, "2011-2012 Öğretim Yllında Uygulanan Din Kültürü ve Ahlak Bilgisi Dersi Programına İlişkin Bir Değerlendirme” başlıklı çalışmada UNESCO ve UNICEF’in hakların evrenselliği ve vazgeçilmezliği, hakların bütünselliği, eşitlik ilkesi ve ayrımcılık yasağ1 hesap verebilirlik ve hukukun üstünlüğüne sayg1 gibi öğelerini ortaya koyduğu eğitime insan hakları temelli yaklaşım konusunda Toledo ilkelerine göre, dinler hakkında öğretim, hassas, dengeleyici, kapsayıcı olması gerektiği, ancak zorunlu DKAB dersinin büyük oranda belli bir dini (Sünni İslamı) öğretmesi ve Hiristiyan ve Yahudi öğrenciler dışında tüm öğrenciler için zorunlu olması açısından eşitlik ilkesi ve ayrımcılık yasağına aykırılık oluşturduğunun altını çizmiştir. Türkiye'de farklı dinlere ve mezheplere mensup öğrenciler için benzer bir ders sağlamayarak eşitlik ilkesini çiğnemekte, sadece Hıristiyan ve Yahudi öğrencilere muafiyet sağlayarak da ayrımcılık yapıldığı üzerinde durmuştur. (Yıldırım, 2012: 11-12) DKAB dersi 7. Sınıf kitabında "cemevi cemin yapıldığı yer olarak nitelenecektir" şeklindeki ifadeyle cemevinin bir ibadet yeri olduğunun ifade edilmesinden kaçınılarak, Alevi toplumunda cemevinin bir ibadet yeri olması yönündeki yaygın kabulün reddedildiğine vurgu yapılmıştır. (Y1ldirim, 2012: 3)

Rapor, ayrıca, 2011-2012 öğretim yılında DKAB dersi öğretim programında yapılan değişikliklerin tarafsızlık ve nesnellik gibi belli ilkeler esas alınarak, programın tümünün gözden geçirilmesi yerine, değişikliklerin programa bazı yeni eklemelerin yapılması seklinde olduğunun altını çizmiştir. (Yıldırım, 2012: 2) Yaman, ise söz konusu eklemeleri kalıcı ve objektif bir yaklaşımla çözüm üretmek yerine yapılan yüzeysel değişiklikler olarak ifade edip değişiklikleri "yama” olarak nitelemektedir. (Yaman, 2013)

AİHM, sonuç olarak, zorunlu din derslerinin AİHS'nin düşünce, din ve vicdan özgürlüğünü düzenleyen 9. maddesi ile ayrımcılık yasağını düzenleyen 14. maddesine aykırı olduğu, Avrupa ülkelerindeki din eğitimi uygulamaları örnek gösterilerek, dini bir 
yoruma diğer inançlara göre ayrıcalık tanınamayacağı, durumun bu haliyle devamının mümkün olmadığı sonucuna varmıştır. Ayrıca, hükümetin önerdiği muafiyet yönteminin de bireylerin dini kanaatlerini açıklamaya zorlayacağ1 gerekçesiyle karş1 çıkmıştır. Ancak, zorunlu din dersleri konusunda geçen zaman içinde bir ilerleme sağlanamamıştır.

\section{Cumhuriyetçi Eğitim ve Kültür Merkezi Vakfı/Türkiye Davası,}

Cumhuriyetçi Eğitim ve Kültür Merkezi Vakfı (Cem Vakfi), 2010 yılında AİHM'nde camilerin elektrik faturalarının Diyanet İşleri Başkanlığı (DİB) tarafından ödendiği, ancak Alevilerin ibadethane olarak kabul ettikleri, cemevlerinin elektrik faturalarının DİB tarafından ödenmediği gerekçesiyle dava açtı. (AİHM: 'Alevilere ayrımcılık yapılıyor', 2014) Adalet ve Kalkınma Partisi (AKP) hükümeti, AİHM önünde söz konusu Yenibosna Cemevi’ne "indirimli elektrik faturası" uygulandı̆̆1 iddiasını dile getirmiştir. Mahkeme, cemevlerini "ibadethane" olarak kabul etmiş ve DİB'nın diğer ibadethanelerde yaptığı gibi cemevlerinin elektrik faturalarını ödemesi gerektiği; “indirimli elektrik faturası"nın cemevlerine uygulanan söz konusu ayrımc1lı̆g1 ortadan kaldırmayan bir uygulama olması nedeniyle yeterli bulmamıştır. Mahkeme, bu kapsamda "dini temele dayalı uygulamada" bulunulduğu ve bu uygulamanın hiçbir “objektif ve akla yatkın gerekçeye dayanmadı̆̆ı”, dolayısıyla da hükümetin AİHS'nin 9. maddesiyle bağlantılı olarak 14. maddesini ihlal ettiği sonucuna ulaşmıştır. Yani, dava konusu olay "elektrik faturası" olsa da AİHM'nin hükümetin Alevilere karşı ayrımcılık yaptığını ortaya net olarak koyması bakımından çok önemli bir davadır.

AİHM, devletin tüm dini inançlar karşısında "yansız ve tarafsız" kalmakla yükümlü olduğunu hatırlatarak, düşünce, din ve vicdan özgürlüğünün demokratik toplumun "temel direklerinden" olduğunu ve söz konusu özgürlüğün inananların yanı sıra ateistler, agnostikler, şüpheciler ve inanç konusunu umursamayanlar için de değerli bir kazanım olduğunun altını çizmiştir. (Cumhuriyetçi Eğitim ve Kültür Merkezi Vakfi/Türkiye Davası, Başvuru No: 32093/10)

AİHM'ye göre, şayet bir devlet, ibadethaneler için ayrıcalıklı bir statü belirlerse, bu statüyü talep eden bütün dini gruplara, söz konusu statüden hakkaniyete uygun olarak faydalanmayı talep etme imkanı sunulması gerekmektedir. Davada, sonuç olarak, Cem Vakfi'nın maruz kaldığı muamele farklılı̆̆ının, nesnel ve makul bir gerekçesinin bulunmadığı ve ibadethanelere uygulanan elektrik faturalarının ödenmesinden muaf tutulma konusuna ilişkin düzenlemenin, dine dayalı bir ayrımcılık teşkil ettiği 
sonucuna varmıştır. (Cumhuriyetçi Eğitim ve Kültür Merkezi Vakfi/Türkiye Davası, Başvuru No: 32093/10)

AİHM kararları sonrasında, Yargitay da AİHM içtihadını dikkate alarak, cemevleriyle ilgili iki önemli karar almıştır. Bu davalardan birincisi, Çankaya Cemevi Yaptırma Derneği'nin kapatılması istemiyle açılan davada, Yargıtay, cemevlerinin ibadethane olup olmadığının yarg1 kararıyla belirlenemeyeceği yönünde bir karar vermiştir. (Norwegian Helsinki Committee, 2015: 18) Yarg1tay Hukuk Genel Kurulu, oy çokluğuyla ilgili aldığı söz konusu kararda, dernek tüzüğünde yer alan cemevi yaptırılmasına ilişkin maddelerin, 677 Sayılı Tekke ve Zaviyelerin Kapatılmasına İlişkin Kanun'a aykırı olsa da Türkiye Cumhuriyeti Anayasasının 90. maddesindeki "temel hak ve özgürlüklere ilişkin milletlerarası antlaşmalarla kanunlarn aym konuda farkh bükümler içermesi nedeniyle çıabilecek uyusmąlıklarda milletlerarası antlaşma bükümleri esas alını" ifadeleri dayanak kabul ederek, cemevi açmak ve yaptırmak için dernek kurulabileceğine hükmetmiştir. (Habertürk, 2014)

Ardından, Yargitay'in cemevlerine elektrik faturası tahakkuk ettirilmesi konusunda açılan dava ile ilgili olarak verdiği çok önemli bir kararına (Esas No: 2014/11238, Karar No: 2015/9711) değinmek yerinde olur. Yargıtay 3. Hukuk Dairesi kararında AİHS’nin “ayrımcılık” başlıklı 14. maddesi ve "Düşünce, vicdan ve din özgürlüğü” maddelerinin yanı sıra "Anayasanın 90. maddesinin "Usulüne göre yürürlüğe konulmus temel hak ve özgürlüklere ilişkin milletler arası antlasmalarla kanunlarn aym konuda farkh bükümler içermesi nedeniyle çleabilecek uyusmąlıklarda milletlerarası antlaşma bükümleri esas almn?" şeklindeki hükmüne atıfta bulunarak, Alevilik ve Alevilerle ilgili sorunların Türkiye'de ve Avrupa İnsan Hakları Mahkemesi'nde yargılama konusu olduğu, Cumhuriyetçi Eğitim ve Kültür Merkezi Vakfı/Türkiye Davası'na (Başvuru No: 32093/10) AİHM'nin Türkiye'nin İHAS'ın 9. ve 14. maddelerini ihlal ettiğine hükmettiğinin altını çizen söz konusu kararla, cemevinin Alevi-İslam inanışına sahip yurttaşlarımızın öteden beri cem ibadetini yaptıkları mekanın adı olduğu, tüm alevi toplumunca kabul gören cemevlerinin Alevi İslam anlayışına sahip yurttaşların ibadet mekanı olduğunun altı çizilerek öncelikle, bir mekanın ibadet yeri sayılıp sayılmamasının münhasıran o inanca sahip kişilerin takdirinde bulunması gerektiğine karar vermiştir. Kararda ayrıca, Alevi inancına mensup insanların inanç ve ibadet merkezlerinin cemevleri olduğu Alevilerle birlikte tüm toplum kesimleri tarafindan kabul edilmiş bir olgu ve gerçeklik olduğu ifade edilmiştir. Türk yargısı ilk kez bir mekanın ibadethane olup olmayacağına resmi otoritenin değil, o inanç üyelerinin karar vermesi gerektiğinin 
altını çizerek, cemevlerinin ibadethane kapsamında değerlendirilmesi gerektiğine hükmetmiştir. (Esas No: 2014/11238, Karar No: 2015/9711)

Söz konusu dava, devletin tarafsız olması gerektiğine vurgu yaparak, din ve vicdan özgürlüğünün demokratik toplumun temel direklerinden biri olduğu ve bu kapsamda Alevilerin ayrımcılığa maruz kaldığı ve Alevilere uygulanan "muamele farklılığının" makul bir gerekçesinin de bulunmadığının altını çizmiştir.

\section{AİHM'nin Son Sözü}

2005 yılında Başbakanlığa başvurup Diyanet İşleri Başkanlığı'nın yalnız Sünni vatandaşlara değil, bunların yanı sıra, Alevilik ve diğer inançları da kapsayacak şekilde kamu hizmeti vermesi talebinde bulunan Cem Vakfi'nın, Aleviliğe hukuksal statü tanınması, cemevlerinin ibadethane olarak tanınması, cemevlerinin inşasına imkan tanınması ve Alevi dedelerine, Sünni din adamlarında olduğu gibi maaş bağlanması talepleri de 19 A ğustos 2005 tarihinde Başbakanlık tarafindan reddedildi. Başbakanlığın bu ret yanıtı üzerine, 1919 Alevi vatandaş Başbakanlı̆̆1 Türk mahkemelerine şikayet etti. Ancak, mahkemeler Başbakanlığın red yanıtının yürürlükteki yasalarla uyumlu olduğuna hükmetti. (AİHM'de Aleviler için tarihi karar, www.dw.com/tr, 2016) Bu karar, 2 Şubat 2010 tarihinde Danıştay tarafindan da onandı. Bunun üzerine Cem Vakfı Başkanı İzzettin Doğan 202 kişiyle birlikte konuyu 2010 yılında AİHM gündemine taşıdı. 2013 yılında görülmeye başlanan davanın kapsam ve önemini göz önünde bulunduran yetkili ikinci daire, davaya kendisi bakmak yerine, 25 Kasım 2014 tarihli oturumunda Büyük Daire lehine dosyadan el çekmiş, dosyayı kararları kesin olan 17 yargıçlı Büyük Daire’ye göndermiştir. (Cem Vakfı, 2016: 6)

AİHM'nin Alevilerle ilgili kararları dairelerin verdiği kararların aksine kararları kesin olan, içtihat niteliği taşıyan ve AİHM'nin temyiz organı olarak görev yapan Büyük Daire'nin kararı, Türkiye açısından bağlayıcıdır, zira Avrupa Konseyi Bakanlar Komitesi söz konusu kararın yerine getirilip getirilmeyeceğini denetlemektedir.

Davacılar AİHM'ye sundukları iddianamede, Alevilerin devletin sağladığı din hizmet ve olanaklarından yararlanamaması ve bu hizmetin yalnız Sünni İslama mensup Müslümanlara verilmesinin Avrupa İnsan Hakları Sözleşmesi’nin 'Düşünce, vicdan ve din özgürlügü" başl1kl1 "Herkes düsünce, vicdan ve din özgürlügüne sahiptir. Bu

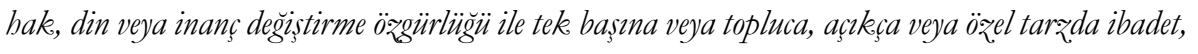
ögretim, uygulama ve ayin yapmak suretiyle dinini veya inancın açıllama ö̈gürlügü̈ü de içerir..." 
şeklindeki 9. maddesine ve AİHS’nin ayrımcılıkla ilgili “Ayrımcılık yasağı” başlıklı " $B u$ sözleşmede tanman hak ve özgürlüklerden yararlanma, cinsiyet, diğer kanaatler, ulusal veya toplumsal köken, ulusal bir azınliğa aidiyet, servet, doğum bașta olmak üzere herhangi başka bir duruma dayah hiçbir ayrmollı gözetmeksiz̨in sağlanmalıdır" şeklindeki 14. maddesine aykırı olduğunu savundu.

Hükümet, AİHM önünde kendini, Alevilerin kendi aralarında "homojen bir yapıya" sahip olmadıkları, devletin dinlere karşı "tarafsız ve yansız" olduğu, "Diyanetin İslamin sufi yorumuna hizmet vermediği”, cemevlerinin cami, mescit, kilise ve sinagogların aksine ibadethane kategorisine girmediği tezleriyle savundu. Alevilerin kendilerini "İslamın sufi, rasyonalist ve pratik bir yorumu" olarak gördüklerini belirten hükümet, Alevi inancının “ne tam olarak bir din ne de İslam'ın bir dalı olarak görülemeyeceği, sufi tarikatı olarak ele alınması gerektiğì" şeklindeki tezi (AİHM'den Aleviler için tarihi karar, www.dw.com/tr) AİHM'de kabul görmedi. Dini toplulukların ne olduklarına devlet veya ulusal yargının değil söz konusu toplulukların ruhani liderlerinin karar verebileceğine işaret eden AİHM, hükümetin Alevileri "Sufi tarikatı" olarak tanımlamasının Alevileri dini inançlara yasaklar getiren 677 sayılı "Tekke ve Zaviyelerle Türbelerin ve Türbedarlıklar ile Bir Takım Unvanların Men ve İlgasına Dair Kanun” kapsamına aldığını hatırlattı. Türk Hükümetinin “Aleviler kendi aralarında bölünmüş haldeler" tezine "bu durum onların dini bir topluluk olarak hakları olduğu gerçeğini değiştirmez” yanıtını vermiştir. (AİHM’den Aleviler için tarihi karar, www.dw.com/tr)

Kararında 2009-2010 yıllarında Türkiye'de hükümetin Alevi kuruluşlarıyla birlikte düzenlediği Alevi çalıştaylarının sonuç raporlarını temel alan AİHM, devletin Alevileri resmen tanımaması ve hukuksal statü sağlamamasıyla, AİHS'nin din ve vicdan özgürlügüule ilgili 9. maddesinin ihlal edildiği sonucuna varmış, ayrıca, Alevilerin hiçbir kamusal hizmetten yararlanmamalarını da "dini ayrımcılık" olarak tanımlamıştır. Alevi inancını inkarın "laik devleti koruma" teziyle gerekçelendirilmesini de reddeden AİHM, Türkiye'de dini inançlarla ilgili hukuksal yapının "nötr" kriterlere dayanmadı̆̆ını ve durumun bazı inançların ayrımcılı̆̆a maruz kalmasına neden olduğunun altını çizmiştir.

Türmen'e göre, AİHM Büyük Dairesi'nin söz konusu kararının önemi, AİHM'nin Alevilerle ilgili daha önce dairelerin verdiği kararlardan farklı olarak, zorunlu din dersleri, cemevlerinin statüsü ve nüfus kağıtlarındaki din hanesi ilgili davalardaki gibi Alevilerin yalnız belli sorunlarıyla ilgili değil, Alevi sorununun temeline inerek, 
Aleviliğin ayrı bir inanç olarak tanınması konusunu ele almıştır. Zira, bütün sorunlar bu tanımamadan kaynaklanmaktadır. (Türmen, 07.05.2016)

Söz konusu davada, davacılar, İHAS’ın 14. maddesiyle bağlantılı olarak 9. maddeye dayanarak, dinlerini açıklama özgürlüklerinin iç hukuk kapsamında yeterli şekilde korunmadığını ileri sürmüşlerdir. İslamın Sünni mezhebine bağlı olan vatandaşlara sunulan dini kamu hizmetlerinin, Alevi inancını benimseyenler için de sunulması yönündeki taleplerinin reddedilmesi hususunda şikayetçi olmuşlar ve ayrımcılık mağduru olduklarını iddia etmişlerdir. Bu durumun devletin dini inançlar karşısında tarafsız ve bağımsız görevinin ihlalini teşkil ettiğini ileri sürmüşlerdir. (İzzettin Doğan ve Diğerleri/ Türkiye Davası, (Başvuru No.62649/10))

Doğan ve diğer davacilar, tüm vatandaşlarca ödenen vergilerle oluşan genel bütçeden milyarlarca lira alan Diyanet İşleri Başkanlığı'nın uygulamada kendisini yalnızca Sünni mezhep ile sınırladığı, Sünni mezhep dışında kalan Alevileri ve diğer inanç mensuplarını yok saydı̆̆ını ve Sünni mezhebi merkeze alarak Alevi vatandaşların tüm taleplerini reddettiğini, Alevi vatandaşların din ve vicdan hak ve özgürlüğünün yok sayıldığı, devletin din ve vicdan özgürlüğünün tam olarak kullanılabilmesi için gerekli her türlü tedbiri alması ve güvenceleri sağlamakla yükümlü olduğu Anayasal düzenleme ve uluslararası sözleşmelerle açıkça kabul edilmiş olmasına rağmen, cemevleri ibadethane olarak kabul edilmemekte, cemevlerinin yapilması konusunda zorluklar çıkarılmakta, dini hizmetlerin sunulması için yer ve genel bütçeden kaynak tahsis edilmediği ve hak ve özgürlüklerin kullanılmasının adeta kamu görevlilerinin kişisel inisiyatiflerine terk edildiğini ifade etmişlerdir. (İzzettin Doğan ve Diğerleri/ Türkiye Davası, (Başvuru No.62649/10))

Davacılar, AİHS'ndeki anlamıyla din özgürlüğü taraf devletlere, dini inançlar ya da bu dini inançların ifade edilme yollarının meşruluğu üzerinde bir takdir yetkisi tanımayacağını vurgulamışlardır. Öte yandan, Diyanet İşleri Başkanlığı, Aleviliği tasavvuf etkili ve belirli kültürel özellikleri bulunan bir İslam yorumu olarak görmekte, tek başına bir din ya da mezhep olarak görülemeyeceği görüşündedir. Hükümet temsilcileri, DİB’in görevlerini laiklik ilkesine göre yaptı̆̆ını, belirli bir grubun ya da tarikatın tercihlerini dikkate almadan, tüm Müslümanlarca kabul edilen İslam dininin kaynakları temelinde yerine getirdiğini ifade etmiştir. (İzzettin Doğan ve Diğerleri/ Türkiye Davası, (Başvuru No.62649/10)) 
Hükümet, 30 Kasım 1925 tarihli ve 677 Sayılı Tekke ve Zaviyelerle Türbelerin Seddine ve Türbedarlıklar ile Bir Takım Unvanların Men ve İlgasına Dair Kanun ile şeyhlik, dervişlik, müritlik, dedelik, çelebilik ve babalık gibi unvan ve sıfatların kullanılmasının yasakladı̆̆ının ve söz konusu unvanlarla bağlantılı tasavvufi ibadetlerin yerine getirilmesi için ibadethane tahsis edilmesinin yasaklandığı, ancak buna rağmen hükümetin Alevilere karşı hoşgörülü bir tutum benimsediğinin altını çizerek, Alevilerin dinsel törenler düzenleyebildiğini ve 677 Sayılı Kanun'un günümüzde uygulanmadığını ifade ederek din ve devlet ilişkileri konusunda devletin çok geniş takdir hakkı olduğunu ifade etmişlerdir. Hükümet, Aleviliği bir inanç olarak görmeyip, İslamın farklı bir yorumuna dayanan bir sufi tarikat olarak görmekte ve ibadethane ile sufi tarikatlarının toplanma yerlerinin birbirinden farklı olduğunu iddia etmiştir. Ayrıca, Türkiye'de cemevleri yapma önünde herhangi bir güçlük bulunmadığını da ifade eden Hükümet, Alevilerin bir bütün olmadıkları kendi aralarında anlaşamadıklarını da ifade etmiştir. (İzzettin Doğan ve Diğerleri/ Türkiye Davas1, (Başvuru No.62649/10))

AİHM, Venedik Komisyonu'nun raporuna atıfta bulunarak, "bir dinin devlet dini olarak tanmması, resmi veya geleneksel din olarak kabul edilmesi veya söz konusu dine inananlarn nüfusun büÿ̈k çoğunluğunu olusturması özel statü tanıma konusunda kabul edilebilir bir gerekçe oluşturabilmekle birlikete, bunun diğer dinlere inananlarn veya inançsı̨̧larm bir insan haker ve temel özgürlükten yararlanma bakımmdan herhangi bir engel yaratmaması veya bu kesimlere yönelik herhangi bir ayrmallăga yol açmaması gerekir... Tüzel kişilike hakekı, din veya inançözgürlüklerini kullanmak isteyen kişi veya topluluklarm bu yöndeki ebliyetlerini herhangi bir sekilde tescil islemlerine veya benzeri kusitlamalara tabi kulmak suretiyle haklarm kusitlayan bir araç olarak kullamlarak suistimal edilmemelidir' şeklinde tüzel kişiliğe vurgu yapmaktadır. Ayrıca, tüzel kişiliğe erişimin mümkün olduğunca çok sayıda topluluğa açık olması gerektiğinin altını çizmiştir. Tüzel kişiliğin, herhangi bir topluluktan geleneksel veya tanınmış bir din veya inanç oluşturmadığı gerekçesiyle esirgenmemesi gerektiği de ifade edilmiştir. (Venedik Komisyonu, CDL-AD (2014)023)

Hükümetin iddia ettiği geniş takdir yetkisiyle ilgili olarak AİHM, devletlere tanınan takdir yetkisinin ölçüsü devletlerin dini mezhep kavramını, bir dinin geleneksel olmayan ve azınlık bir biçimini yasal korumadan yoksun kılacak derecede kısıtlı bir şekilde yorumlamasına izin verdiği takdirde, Sözleşme'nin 9. maddesinde korunan din ve vicdan özgürlüğü hakkı oldukça teorik ve yanıltıcı olacağına hükmetmiştir. 
Dolayısıyla, devletin takdir payını aştığı ve AİHS'nin 9. maddesini ihlal ettiğgi sonucuna varmıştır.

AİHM, din ve inanç özgürlüğünü düzenleyen 9. maddenin sağladığı korumanın temelinde bir dinsel grubun özerk ve otonom olarak bir grup olarak var olmanin yattığının, laik devletin din ve inançlar konusunda tarafsız olması ve herhangi bir din veya inanç konusunda bir tercih belirtmemesi gerektiğinin altını çizerek, hükümetin, Aleviliği bir sufi tarikatı olarak nitelemesinin tarafsız kalma ödeviyle bağdaşmadığının altını çizmiştir. 677 Sayılı Kanunla ilgili olarak, hükümetin Alevilere hoşgörüyle davrandı̆̆ı iddiasına karşı, AİHM, hoşgörünün Alevilerin haklarının tanınmasının yerine geçemeyeceği ifade etmiştir. (Türmen, 07.05.2016) Ayrıca, devletin tarafsızlık görevinin, devletin dini inançlarının ve bu inançların ifade edilme biçimlerinin meşruiyetini değerlendirme yetkisiyle bağdaşmadığının altını çizmiştir. Zira Mahkeme'ye göre, bir dini topluluğun dini mensubiyetini belirlemek devletin değil, sadece söz konusu topluluğun görevidir. (İzzettin Doğan ve Diğerleri/ Türkiye Davas1, (Başvuru No.62649/10))

Türkiye'de devletin din ve inançlara yaklaşımını "hedefle orantısız" olarak tanımlayan AİHM, Alevilere yönelik uygulamanın "akla uygun ve objektif temele dayanmadığına" ve bu nedenle Alevilere "dinsel ayrımcılık" yapıldığına hükmeden AİHM Büyük Dairesi, 26 Nisan 2016 tarihli kararı aleviler hakkında vermiş olduğu son ve temyizi mümkün olmayan nihai kararında (İzzettin Doğan ve Diğerleri/ Türkiye Davas1, (Başvuru No.62649/10)) AİHM, devletin demokratik toplumlarda, dini toplulukların birleşmiş bir liderlik kapsamında olmasını sağlamak amacıyla, tedbirler almasına gerek olmadığını ifade ederek, bölünmüş bir dini topluluğun tek liderin lehine olan veya topluluğu kendi iradesi dişında birleşmiş bir liderlik çatısı altına girmeye zorlamak amacıyla yapılan bir devlet eyleminin de din özgürlügüne müdahale olacağını ifade etmiştir. Yani devletin dinin bir yorumunu diğerine tercih etmemesi gerektiğini ifade eden Mahkeme, din ve vicdan özgürlüğünü düzenleyen 9. maddeye ilişkin kararlarında sürekli olarak vurguladığı bir hususu yineleyerek, devletin tarafsılık görevinin, dini inançların ve bu inançların ifade edilme biçimlerinin meşruiyetini belirleme konusunda devletin herhangi bir takdir yetkisine sahip olmasını önlediğine hükmetmiştir.

Hükümetin bir diğer iddiası olan Alevilerin kendi inançları üzerinde fikir birliğinde olmamaları tezine karşın, AİHM, Alevilerin inançları konusunda farklı fikirlerde olmalarının hükümetin Alevi inancını tanımamasını haklı gösteremeyeceğini, 
dolayısıyla da hükümetin Avrupa İnsan Hakları Sözleşmesi'nin (AİHS) din ve inanç özgürlüğünü düzenleyen 9. maddesini ihlal ettiği sonucuna varmıştır.

\section{Sonuç}

Mahkeme tüm bu kararlarında sonuç olarak, Alevilere dini ayrımcılık yapıldığı kanaatine varmış ve Aleviliğin resmen tanınması gerektiğine hükmetmiştir. AİHM'ye göre, bir dini topluluk olarak Alevilerin özerk bir varlı̆ga sahip olma hakkı, demokratik bir rejimin olmazsa olmaz ilkesi olan çoğulculuk ilkesi açısından zorunludur ve AİHS'nin 9. maddesinde yer alan güvencelerin de temelini oluşturmaktadır. Türkiye Cumhuriyeti Anayasası'nın 90. maddesinin “Usulüne göre yürürlüğe konulmuş temel hak ve özgürlüklere ilişkin milletlerarası antlaşmalarla kanunlarn ayn konuda farklı bükü̈ler içermesi nedeniyle çıkabilecek uyuşmąlıklarda milletlerarası antlaşma bükë̈mleri esas alınır" şeklindeki hükmüne vurgu yaparak, devlet makamlarının Alevi topluluğuna, dini uygulamalarına ve mabetlerine yönelik tutumunun devletin tarafsılılk göreviyle ve dini toplulukların özerk olarak var olma hakkıyla bağdaşmadığı kanaatine varmıştır.

AİHM, en son verdiği kararda ayrıca, kamunun sunduğu dini hizmetlerden yararlananlarla Aleviler arasında apaçık bir dengesizlik bulunduğu, Alevi toplumunun tarikat olarak görüldüğü, çok sayıda kısıtlamayla karşılaştığ1 ve kamunun sunduğu dini hizmetlerden yararlanamadığı sonucuna varmıştır. Dolayısıyla, devlet farklı inançlar ve aynı din içindeki farklı kollar konusunda tarafsız olmalıdır. Devletin farklı inançların gereklerinin yerine getirilmesindeki tarafsız olma yükümlülüğ̈ kapsamında, devletin inançların meşru olup olmadığını takdir etme hakkı yoktur.

Aleviliğin tanınmamasının "laik devleti koruma” teziylegerekçelendirilemeyeceğine hükmeden AİHM, (Çalışlar, 2016) hükümete son söz olarak Alevilerin maruz kaldığ1 muamele farklılığının objektif ve makul hiçbir gerekçesinin bulunmadığını ifade etmiş ve Alevilerin kamusal hizmetten yararlanmamalarını, "dini ayrımcılık" olarak nitelemiştir.

Adalet ve Kalkınma Partisi Hükümeti, Alevilerin sorunlarının tartışıldığı bir dizi Alevi Çalıştayları düzenlemiş, ancak herhangi bir somut sonuç elde edilememiştir. Yapılması gereken söz konusu ihlale son verecek düzenlemeler yapmaktır. Alevilerin AİHM ve AB tarafından tanınan hakları Türkiye Cumhuriyeti hükümeti tarafindan da zaman geçirilmeden kabullenilip uygulanmalıdır. Henüz bir resmi statü verilmeyen ve fiili bir durum olarak (de facto) varlı̆̆ını sürdüren cemevleri yasal statüye 
kavuşturulmalıdır. Bu kapsamda, halihazırda Alevilerin dini inançlarını serbestçe yaşamaları, ancak idari yetkililerin iyi niyetine dayanmaktadır. Oysa ki Mahkeme, hükümet tarafindan Alevi topluluğuna gösterildiği iddia edilen müsamahayı, Alevilere haklarının verilmesini sağlayabilecek yegane yol olan tanımanın alternatifi olarak değerlendirilemeyeceğini çok açık olarak ifade etmiştir.

Aleviliğin Sünni İslamdan ayrı bir dini mezhep olarak tanınmaması, Aleviliğin kendine özgü dini özelliklerinin inkarı anlamına gelmektedir. Alevi topluluğu tüzel kişiliğe sahip olmadığı için kendi başına mahkemelerde dava açamamakta, bunu vakıf ve dernekler vasıtasıyla yaptıkları zaman da pek çok hukuki engelle karşılaşmaktadırlar. Sünni bir bakış açısıyla Alevilik öğretisini tanımlamaya çalışmanın muhtemelen yanlış bir tanıma götürecektir. Örneğin, "Alevilik Hz. Ali'yi sevmekse biz de Aleviyiz” gibi bir bakış açısı böyle bir tanımlama çabasıdır ve Aleviliğin temel felsefesinin bütününü görememektedir. Dolayısıyla, Aleviliği tanımlama görevi yalnızca ve bütünüyle Alevilere bırakılmalıdır. Tanım konusunda Aleviler arasında oluşan fikir ayrılıkları olması, Alevilerin dini bir topluluk olduğu gerçeğini değiştirmez.

Irkçılığa ve Hoşgörüsüzlüğe Karşı Avrupa Komisyonu (ECRI) da hükümeti Alevi toplumuyla yapıcı bir diyalog inşa etmeye ve iyi ilişkiler kurmaya çağırmaktadır. (ECRI, 2011) Alevilerin resmi olarak tanınmaması, Türkiye'nin laik, demokratik ve Avrupa Birliği'yle müzakere eden bir aday ülke olarak içerde ve dışardaki saygınlığına zarar vermektedir. Bu olumsuz durumdan çıkmak, ancak Aleviliğin tanınmasıyla mümkün olacaktır. Aleviliğin resmi olarak tanınması, ülkemizin birlik ve bütünlügüne ve iç barışına çok önemli katkılarda bulunacak, Avrupa Birliği müzakere sürecinde temel haklar başlı̆̆ı altında önemli bir ilerleme sağlayacak ve demokrasi standardımızın yükselmesinde bir kilometre taşı olacaktır. 
"ABD raporu yayınlandı: Türkiye bu yıl "ihlal” rekoru kırdı", Cumhuriyet, 14 Nisan 2016,

"AİHM: Alevilere ayrimcilik yapiliyor", 02.12.2014, http://www. dw.com/tr/aihm-alevilere-ayr $\%$ C $4 \%$ B 1 mc $\%$ C $4 \%$ B $11 \%$ C $4 \%$ B $1 \mathrm{k}$ yap $\% C 4 \% B 11 \% C 4 \% B 1$ yor/a-18105954 (03.06.2016)

"AİHM'den Aleviler için tarihi karar", (26.04.2016) www.dw.com/tr/aihmdenaleviler-için-tarihi-karar/a-19215641, (28.05.2016)

Avrupa İnsan Hakları Mahkemesi, Karar, Mansur Yalçın ve Diğerleri/Türkiye Davas1, (Başvuru No. 21163/11), Strazburg, 16 Eylül 2014,

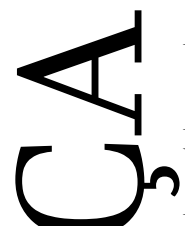

Avrupa İnsan Hakları Mahkemesi, Karar, Hasan ve Eylem Zengin -Türkiye (Başvuru No. 1448/04) Strazburg, 9 Ekim 2007.

Avrupa İnsan Hakları Mahkemesi, Karar, Cumhuriyetçi Eğitim ve Kültür Merkezi Vakfi/Türkiye Davası, Başvuru No: 32093/10, Strazburg, 2 Aralık 2014.

Avrupa İnsan Hakları Mahkemesi, Büyük Daire Karar, İzzettin Doğan ve Diğerleri/ Türkiye Davası (Başvuru No.62649/10) Strazburg, 26 Nisan 2016.

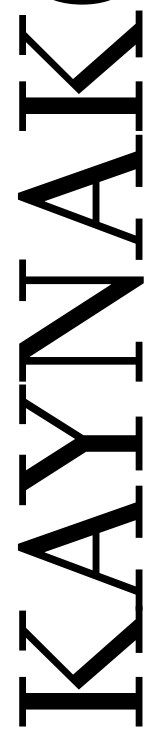

ÇALIŞLAR, Oral, "İktidarın Alevilik açmazı”, http://www.posta.com.tr/turkiye/ YazarHaberDetay/Iktidarin-Alevilik-acmazi.htm?ArticleID=340231, (28.07.2016). European Commission For Democracy Through Law (Venice Commission) and OSCE Office For Democratic Institutions and Human Rights (OSCE/ODIHR) Joint Guidelines on The Legal Personality of Religious or Belief Communities, Adopted by the Venice Commisson at its 99th Plenary Session, CDL-AD (2014)023. KILIÇ, Mustafa Cemil, 23 Ocak 2013, "Din Dersi Sorunu”, http://haberiniz.com. tr/kose-yazisi/70257/din-dersi-sorunu--mustafa-cemil-kilic.html, (29.05.2016).

Irkçlık ve Hoşgörüsüzlüğe Karşı Avrupa Komisyonu Üçüncü Türkiye Raporu, 25 Haziran 2004, http://www.coe.int/t/dghl/monitoring/ecri/Country-by-country/ Turkey/TUR-CbC-III-2005-5-TUR.pdf.

Irkçllık ve Hoşgörüsüzlüğe Karşı Avrupa Komisyonu (ECRI) Türkiye Raporu, CRI (2011)5 (Dördüncü İzleme Dönemi) Kabul tarihi: 10 Aralık 2010, Yayın tarihi: 8 Şubat 2011, http://www.coe.int/t/dghl/monitoring/ecri/Country-by-country/ Turkey/TUR-CbC-III-2005-5-TUR.pdf.

Norwegian Helsinki Committee, Türkiye'de İnanç Özgürlüğü Hakkını İzleme Raporu, Temmuz 2014- Haziran 2015, http://inancozgurlugugirisimi.org/wpcontent/uploads $/ 2015 / 10 / \mathrm{T} \% \mathrm{C} 3 \%$ BCrkiyede- $\% \mathrm{C} 4 \% \mathrm{~B} 0$ nan $\% \mathrm{C} 3 \% \mathrm{~A} 7-\% \mathrm{C} 3$ $\% 96 \mathrm{zg} \% \mathrm{C} 3 \% \mathrm{BCrl} \% \mathrm{C} 3 \% \mathrm{BC} \% \mathrm{C} 4 \% 9 \mathrm{~F} \% \mathrm{C} 3 \% \mathrm{BC}-\mathrm{Hakk} \% \mathrm{C} 4 \% \mathrm{~B} 1 \mathrm{n} \% \mathrm{C} 4 \% \mathrm{~B} 1-$ \%C4\%B0zleme-Raporu-2015.pdf, (01.08.2016).

Resolution Res (2002)8. On the Statute of the European Commission against Racism and Intolerance http://www.coe.int/t/dghl/monitoring/ecri/About/ Res(2002)8\%20amended $\% 20-\% 20$ Statute $\% 20$ ECRI\%20-\%20revised $\% 20$ February\%202014.pdf

TÜRMEN, Rıza, "AİHM'in Aleviler ve cemevleri ile ilgili kararı hangi gerekçelere dayaniyor?", http://t24.com.tr/yazarlar/riza-turmen/aihmin-aleviler-vecemevleri-ile-ilgili-karari-hangi-gerekçelere-dayaniyor, 14502, (24.06.2016). 
YAMAN, Ali, Alevilik ve Kızılbaşlık Tarihi, Nokta Kitap, 2007, İstanbul.

YAMAN, Ali, “Çoğulcu “Mezheplerüstü”lük ve Çoğunlukçu Mezhepçilik Arasında: Zorunlu Din Eğitimi”, (Ocak 2013), http://ps-europe.org/tr/cogulcumezheplerustuluk-ve-cogunlukcu-mezhepcilik-arasinda-zorunlu-din-egitimi/, (11.08.2016).

Yargıtay Kararı, Yargıtay 3. Hukuk Dairesi Başkanlı̆̆1 (Esas No: 2014/11238Karar No: 2015/9711).

"Yargitay: Cemevi yaptırmak için dernek kurulabilir", 03 Aralık 2014, http://www. haberturk.com/gundem/haber/1015418-yargitay-cemevi-yaptirmak-icin-dernekkurulabilir, (01.08.2016).

YILDIRIM, Mine, “2011-2012 Öğretim Yllında Uygulanan Din Kültürü ve Ahlak Bilgisi Dersi Programına İlişkin Bir Değerlendirme” 2012, http://www.aihmiz.org. tr/aktarimlar/dosyalar/1349647350.pdf, 11.08.2016. 
